POLITICS OF NATURE 



\title{
POLITICS OF NATURE
}

\author{
How to Bring the Sciences \\ into Democracy
}

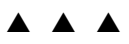

\section{Bruno Latour}

\author{
Translated by \\ Catherine Porter
}

HARVARD UNIVERSITY PRESS

Cambridge, Massachusetts

London, England

2004 
Copyright $\odot 2004$ by the President and Fellows of Harvard College

$$
\text { All rights reserved }
$$

Printed in the United States of America

This book was originally published as Politiques de la nature, by Editions La Découverte, Paris.

\section{LIBRARY OF CONGRESS CATALOGING-IN-PUBLICATION DATA}

Latour, Bruno.

[Politiques de la nature. English]

Politics of nature : how to bring the sciences into

democracy / Bruno Latour ; translated by Catherine Porter.

$$
\text { p. } \mathrm{cm} \text {. }
$$

Includes bibliographical references and index.

ISBN 0-674-01289-5 (cloth) - ISBN o-674-01347-6 (pbk.)

1. Political ecology. I. Title.

JA75.8.L3813 2004

$320.5^{\prime} 8-\mathrm{dc} 22 \quad 2003057134$ 
For Isabelle Stengers, Vinciane Despret, and David Western, three true practitioners of cosmopolitics 
